\title{
Anticonvulsant and reproductive toxicological studies of the imidazole-based histamine H3R antagonist 2-I 8 in mice
}

This article was published in the following Dove Press journal: Drug Design, Development and Therapy

\author{
Salim M Bastaki' \\ Yousef M Abdulrazzaq \\ Mohamed Shafiullah' \\ Małgorzata Więcek ${ }^{3}$ \\ Katarzyna Kieć- \\ Kononowicz ${ }^{3}$ \\ Bassem Sadek'
}

'Department of Pharmacology and Therapeutics, College of Medicine and Health Science, United Arab Emirates University, Al Ain, ${ }^{2}$ Department of Medical Education, Dubai Health Authority, Dubai, UAE; ${ }^{3}$ Department of Technology and Biotechnology of Drugs, Faculty of Pharmacy, Jagiellonian University Medical College, Medyczna, Kraków, Poland
Correspondence: Bassem Sadek Department of Pharmacology and Therapeutics, College of Medicine and Health Sciences, United Arab Emirates University, PO Box 17666, Al Ain, UAE Tel +97I 37137512

Fax+97I 37672033

Email bassem.sadek@uaeu.ac.ae

\begin{abstract}
The imidazole-based H3R antagonist 2-18 with high in vitro H3R antagonist affinity, excellent in vitro selectivity profile, and high in vivo H3R antagonist potency was tested for its anticonvulsant effect in maximal electroshock (MES)-induced convulsions in mice having valproic acid (VPA) as a reference antiepileptic drug (AED). Additionally, H3R antagonist 2-18 was evaluated for its reproductive toxicity in the same animal species. The results show that acute systemic administration (intraperitoneal; i.p.) of H3R antagonist 2-18 (7.5, 15, 30, and $60 \mathrm{mg} / \mathrm{kg}$, i.p.) significantly and dose dependently protected male as well as female mice against MES-induced convulsion. The protective action observed for H3R antagonist 2-18 in both mice sexes was comparable to that of VPA and was reversed when mice were pretreated with the selective H3R agonist $(R)$-alpha-methylhistamine (RAMH, $10 \mathrm{mg} / \mathrm{kg}$, i.p.). Moreover, the results show that acute systemic administration of single $(7.5,15,30$, or $60 \mathrm{mg} / \mathrm{kg}$, i.p.) or multiple doses (15×3 mg/kg, i.p.) of H3R antagonist 2-18 on gestation day (GD) 8 or 13 did not affect the maternal body weight of mice when compared with the control group. Furthermore, no significant differences were observed in the average number of implantations and resorptions between the control and H3R antagonist 2-18-treated group at the early stages of gestation and the organogenesis period. However, oral treatment with H3R antagonist 2-18 $(15 \mathrm{mg} / \mathrm{kg})$ on GD 8 induced a reduced number of live embryos when compared with the i.p.-treated mice. In addition, no significant changes in the fetal body and placental weights were observed after injection of H3R antagonist 2-18 with all selected doses. However, three dose groups of i.p. and oral $15 \mathrm{mg} / \mathrm{kg}$ on GD 13 significantly affected the placental weight when compared with control group. Notably, the treatment of pregnant female with the H3R antagonist 2-18 did not produce significant malformation in the fetus in both groups. In conclusion, the novel H3R antagonist 2-18 proves to be a very safe compound and displays a low incidence of malformations, demonstrating that H3R antagonist 2-18 may have a potential future therapeutic value in epilepsy.
\end{abstract}

Keywords: H3R receptor antagonist, maximal electroshock, anticonvulsant, malformation, gestation, mice

\section{Introduction}

Epilepsy is one of the most common neurological disorders categorized by an unusually excessive neuronal discharge, which is a chief characteristic of epilepsy and is designated as a neurological disorder with recurring seizures. ${ }^{1-3}$ Epilepsy affects millions of people worldwide and is reported to affect about 5-8.4 out of 1,000 people of the population in the US. ${ }^{4}$ In the US alone, approximately 1.3 million women with epilepsy give birth to 25,000 infants each year. ${ }^{5}$ The prevalence rate of epilepsy in other regions is possibly comparable to that of the US. ${ }^{6}$ The prevalence of epilepsy in pregnant women is 
about $0.5 \%{ }^{7,8}$ About $40 \%$ of women with epilepsy are in the child-bearing age group. Epileptic women are more liable to obstetric complications and premature labor than non-epileptic women. ${ }^{8,9}$ The prevalence of major malformations in infants of epileptic parents is twice that of the controls. ${ }^{10-12}$ Both major and minor malformations have been attributed to antiepileptic drugs (AEDs). ${ }^{10,13}$ In addition, many epilepsy patients may also have cognitive problems in addition to suffering from seizures, ${ }^{14-16}$ with the most common cognitive problem being memory deficit. ${ }^{2,17}$ While the causes of reduced memory functions in patients with epilepsy have not yet been completely elucidated, the forms and frequencies of seizures and the side effects of AEDs at therapeutic doses have been described. ${ }^{18-22}$ Consequently, the ideal AED should alter epileptogenesis, suppress seizures, and improve the concomitant cognitive impairments. Interestingly, the role of central histaminergic system involved in epilepsy is driven by growing indications of experimental outcomes that lead to the suggestion that central histamine controls seizure predisposition and thus functions as an anticonvulsant neurotransmitter in electrically as well as chemically induced seizure models in animals. ${ }^{4-17}$ Moreover, the precursor of histamine, namely the amino acid L-histidine, has been found to reduce chemically induced seizure in rats, as it triggers central histaminergic system and increases seizure threshold and decreases seizure tendency mediated by postsynaptically located histamine $\mathrm{H} 1$ receptors (H1Rs). ${ }^{12,17,18}$ Comparable experimental results were also observed in mice lacking histidine decarboxylase enzyme or H1Rs, demonstrating that the central H1Rs have been frequently linked to the development of seizures. ${ }^{27-29}$ Furthermore, it has been found that the clinical use of high doses of numerous centrally acting H1R antagonists, eg, diphenhydramine, as anti-allergic drugs, occasionally stimulate a faster development of convulsions in healthy young children, particularly those receiving antihistamines for a long time. ${ }^{19,20}$ Similar preclinical results were observed in different animal seizure models, and further support the link of brain histaminergic system to the pathophysiology of epileptic seizure. ${ }^{25,29}$

Histamine exerts its effects through binding to four G-protein-coupled H1-4R subtypes, and the H3R firstly described in 1983 was found to be a constitutively active receptor regularly expressed in the brain and pharmacologically regulates histamine synthesis and release, acting as presynaptic autoreceptors..$^{21,22}$ Consequently, ligands capable of increasing central histamine levels, such as histidine and histamine $N$-methyl transferase inhibitors (eg, metoprine), were found to decrease seizures in epileptic patients through H1R stimulation. ${ }^{12,17,23,24}$ Therefore, pharmacological profile of H3R antagonists as future anticonvulsant drugs has begun to attract increased consideration as growing experimental evidence from both acute and chronic models of epilepsy indicated efficiency of H3R antagonists. ${ }^{36,37}$ Accordingly, both imidazole and non-imidazole histamine H3R antagonists provided some protection in the maximal electroshock (MES)-induced convulsion in Wistar rats. ${ }^{11-16}$ Amongst numerous active H3R antagonists produced in both academia and industry, pitolisant (PIT, Bioprojet Biotech), with a marketed application $\left(\right.$ Wakix $^{\mathrm{R}}$ ), was approved in November 2015 by the European Medical Agency as an orphan drug for narcolepsy. ${ }^{12,25-27}$ Also, PIT tested in doses of 20, 40, and $60 \mathrm{mg} / \mathrm{kg}$ significantly suppressed photosensitive epilepsy in $\sim 64 \%$ of investigated patients. ${ }^{28}$ Moreover, and in pursuit of potent histamine H3R antagonists, our research group recently succeeded to develop a series of imidazole histamine H3R antagonists having higher antagonist affinities for human histamine H3Rs than the previous H3R antagonists. One such compound, the imidazole-based H3R antagonist 2-18, dose dependently demonstrated significant protection in MES-induced convulsion model in male adult Wistar rats (Figure 1). ${ }^{29}$ Moreover, subeffective dose of H3R antagonist 2-18 (5 mg/kg, intraperitoneal [i.p.]) significantly potentiated the protective effect in rats pretreated with the standard AED phenytoin ( $5 \mathrm{mg} / \mathrm{kg}$, i.p.), a dose without appreciable protective action when given alone. ${ }^{16}$ Given their localization and their ability to modulate several central neurotransmitter systems and as a continuation of our research, the H3R antagonist 2-18 with high in vitro H3R antagonist affinity, excellent in vitro selectivity profile, and high in vivo H3R antagonist potency was investigated in the current study on its anticonvulsant effects in MES-induced convulsion models in adult mice of both sexes. Moreover, the H3R antagonist

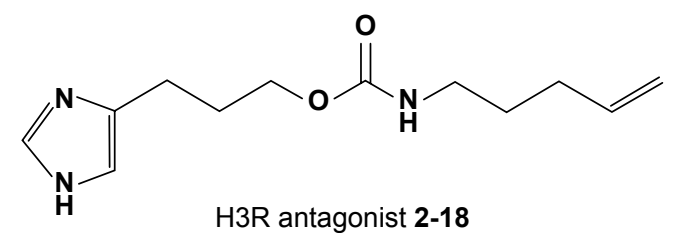

$$
\begin{aligned}
& \mathrm{ED}_{50}=2.3 \pm 0.6(\mathrm{mg} / \mathrm{kg}, \text { p.o. }) \\
& h \mathrm{H} 3 \mathrm{R}\left(p K_{\mathrm{i}}\right)=6.85 \\
& h \mathrm{H} 1 \mathrm{R}\left(p K_{\mathrm{i}}\right)=3.9 \\
& h \mathrm{H} 2 \mathrm{R}\left(p K_{\mathrm{i}}\right)=3.6 \\
& h \mathrm{H} 4 \mathrm{R}\left(p K_{\mathrm{i}}\right)=4.38
\end{aligned}
$$

Figure I Chemical structure, in vitro affinities, and in vivo $\mathrm{H} 3 \mathrm{R}$ antagonist potency of 2-18.

Note: Values previously published. ${ }^{56}$

Abbreviations: $\mathrm{ED}_{50}$, effective dose affecting $50 \%$ of mice receiving the compound 2-I 8; p.o., peroral. 
2-18 was assessed for its reproductive toxicity in the same animal species following its systemic administration in a wide range of doses.

\section{Materials and methods Animals}

All experiments were performed in adult (age of 8-10 weeks) Tuck-Ordinary "TO" mice of both sexes weighing 30-35 g (Harlan, UK). ${ }^{57,58}$ The mice were group housed in standard Plexiglas observation cages in the central animal facility of College of Medicine and Health Sciences on a 12-h light/dark cycle (lights on at 6:00 am). Food and water were available ad libitum. The experiments of the current study were carried out between 9:00 and 12:00 h, and all procedures were performed according to the guidelines of the European Communities Council Directive of November 24, 1986 (86/609/EEC) and were previously approved for epilepsy and teratogenic studies by College of Medicine and Health Sciences/United Arab Emirates University (Institutional Animal Ethics Committee, approval number; ERA-2017-5535 and A14-14, respectively).

\section{Drugs}

H3R agonist RAMH (10 mg/kg, i.p.) and valproic acid (VPA) were purchased from Sigma-Aldrich (St Louis, Missouri, USA). The H3R antagonist $\mathbf{2 - 1 8}$ was synthesized by the Department of Technology and Biotechnology of Drugs (Kraków, Poland) as described previously (Figure 1). ${ }^{29,51}$ Accordingly, the carbamate derivative 2-18 was prepared from the appropriate amine by its reaction with excess of diphosgene, forming an intermediate isocyanate, which subsequently reacted with 3-(1H-imidazol-4-yl)propanol to furnish the desired product, namely $\mathbf{2 - 1 8}$. For the in vivo studies, test compound 2-18, VPA, and RAMH were dissolved in isotonic saline and administered i.p. at a volume of $1 \mathrm{~mL} / \mathrm{kg}$. Doses of H3R antagonist (7.5, 15, 30, and $60 \mathrm{mg} / \mathrm{kg}$, i.p.) and RAMH (10 mg/kg, i.p.) were expressed in terms of the free base. For each test compound, a group of eight animals was used for the anticonvulsant study.

\section{MES-induced seizure}

As previously described, the convulsions were induced in mice with a $50 \mathrm{~Hz}$ alternating current of $120 \mathrm{~mA}$ intensity. ${ }^{10,11,13-16,30,31}$ The current was applied through ear electrodes for $1 \mathrm{~s}$. Protection against the spread of MES-induced convulsion was defined as the abolition of the tonic hind limb extension (THLE) component of the convulsion..$^{10,11,13,15,32,33}$ The animals were divided into groups of eight mice. In the positive control group, mice were injected with VPA at a previously described dose of $300 \mathrm{mg} / \mathrm{kg}$, this being the minimal dose of VPA that protected animals against the spread of MES-induced convulsions without mortality in mice. ${ }^{34-38}$ Animals in the experimental groups were administered test compound 2-18 at doses of $7.5,15,30$, or $60 \mathrm{mg} / \mathrm{kg}$, i.p. 30-45 min before the MES challenge. In a further experiment, a separate group of eight mice received two injections: the first injection contained the most effective dose of H3R antagonist 2-18 and was administered $30 \mathrm{~min}$ prior MES challenge, and the second injection containing RAMH (10 mg/kg, i.p.) was administered 15 min prior the MES challenge.

\section{Statistics}

For statistical comparisons, the software package SPSS 24.0 (IBM Middle East, Dubai, UAE) was used. All data were expressed as means \pm standard error of mean. The effects of H3R antagonist 2-18 on duration of THLE induced in male or female adult mice were analyzed using Kruskal-Wallis test with treatment (saline or test compound). The nonparametric Kruskal-Wallis test was used instead of the one-way ANOVA because the data were not normally distributed. The later was tested using Shapiro-Wilk test. Pairwise comparisons of anticonvulsant effect of H3R antagonist 2-18 between different groups or between male and female adult mice were analyzed using Mann-Whitney test to assess whether there was a significant difference in the duration of THLE between male and female adult mice. The sample size of test groups was small $(n=8)$, therefore a power analysis for male as well as the female mice group was performed and the statistical results showed a beta value of greater than 0.85 (the null hypothesis was correctly [ $85 \%$ ] rejected for the observed results). In all the tests, criterion for statistical significance was $P<0.05$.

\section{Reproductive studies}

Adult female mice, about $30 \mathrm{~g}$ in weight and about 6 weeks of age, were mated with males in the evening, and vaginal plugs identified in the following morning were taken to indicate successful mating. Plug positive day was regarded as day 0 of gestation. Throughout the study, animals of all groups had free access to a commercial chow, and tap water was provided ad libitum. Animals were administered with different doses of H3R antagonist 2-18 (7.5, 15, 30, and $60 \mathrm{mg} / \mathrm{kg}$, i.p.) and another group of animals received three injections containing $15 \mathrm{mg} / \mathrm{kg}$ at 3 hour intervals on gestation day (GD) 8, and to other similar groups of mice on GD 13 (Table 1). Also, similar number of groups of mice $(n=8)$ were treated orally with H3R antagonist 2-18 (7.5, 15,30 , and $60 \mathrm{mg} / \mathrm{kg}$ ). The control groups were injected 


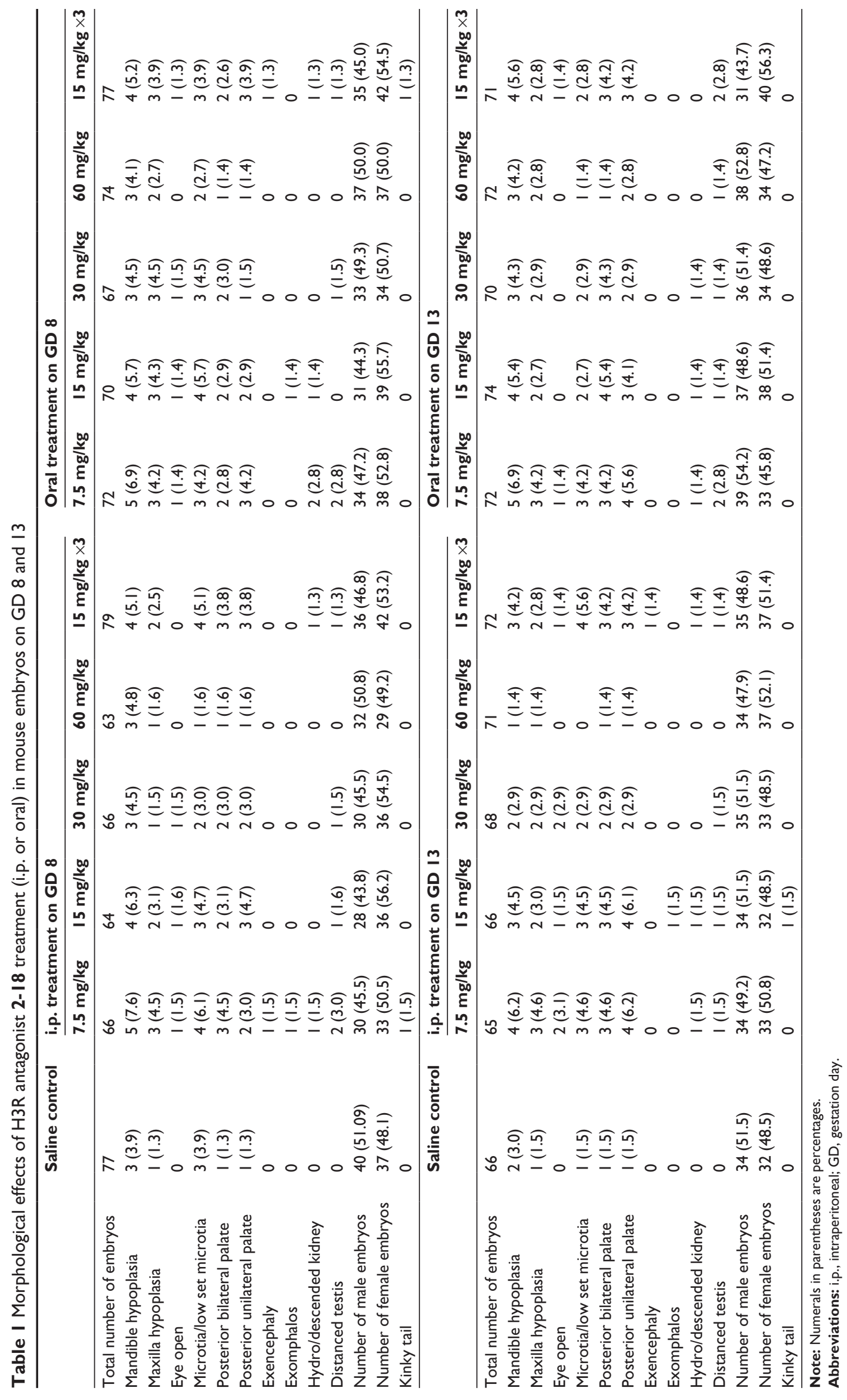


with a proportionate volume of saline (i.p.), and daily food and water consumption by mice in the control groups were recorded. All animals were sacrificed by cervical dislocation on GD 18, and the embryos and placentae were collected. Implantation and resorption sites were noted. The fetuses were blotted dry and weighed and fixed in $95 \%$ ethanol and examined for gross and visceral malformations according to Sterz and Lehmann's method. ${ }^{39}$

\section{Method of whole embryo observation}

The internal malformations were observed by a modified method of Sterz and Lehmann. ${ }^{39}$ The embryos were removed from the $95 \%$ ethanol and observed for any abnormalities with a stereo dissecting microscope by cutting the lower part of the abdomen using a razor blade. All organs were checked and removed by using forceps.

\section{Double staining methods}

Fetuses, without the viscera and skin, were placed in acetone for 1-3 days to eliminate the fat, following which they were stained at $37^{\circ} \mathrm{C}$ for $2-3$ days $(0.3 \%$ filtered alcian blue, $0.1 \%$ filtered alizarin red-S, acetic acid, $70 \%$ ethanol), and washed in water to be cleared of their soft tissues in $0.1 \%$ solution of potassium hydroxide until the skeleton was clearly visible. Then the cleared embryos were placed in an aqueous solution of $20 \%$ glycerin containing $1 \% \mathrm{KOH}$ for $1-5$ days. The clear specimens were placed through $50 \%$ and $80 \%$ glycerin, and stored in $100 \%$ glycerin to observe the malformations with a stereo dissecting microscope. They were then processed and stained with alizarin red-S and alcian blue for detecting bone and cartilage malformations.

\section{Results}

\section{Anticonvulsant effect of $\mathrm{H} 3 \mathrm{R}$ antagonist 2- 18 in MES-induced convulsion model in male adult mice}

The protective activities of acute systemic administration of H3R ligand 2-18 on MES-induced convulsions in male adult mice were examined (Figure 2). The results showed that pretreatment with VPA and H3R antagonist 2-18 (7.5, 15,30 , and $60 \mathrm{mg} / \mathrm{kg}$, i.p.) exhibited a significant protective effect against MES-induced convulsions as confirmed by applying the Kruskal-Wallis test $\left(H_{(7)}=47.65 ; P<0.001\right)$. Pairwise analyses of results showed that male adult mice pretreated with $7.5 \mathrm{mg} / \mathrm{kg}$ of H3R antagonist 2-18 were not protected against convulsions when compared with the saline-treated group with $U=39.50$ and $P=0.441$ (Figure 2). However, substantial amplifications of protective effects

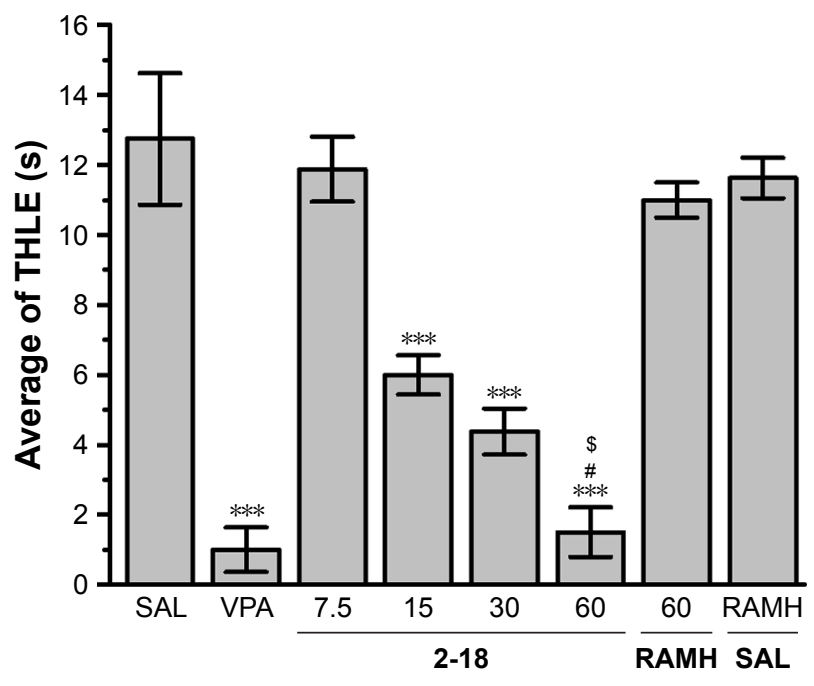

Figure 2 Anticonvulsant effect of acute systemic administration of H3R antagonist 2-I 8 on MES-induced seizure in male adult mice.

Notes: Anticonvulsant effects of VPA (300 mg/kg, i.p.), test compound 2-18 (7.5, 15,30 , and $60 \mathrm{mg} / \mathrm{kg}$, i.p.), and co-injection of test compound 2-18 $(60 \mathrm{mg} / \mathrm{kg}$, i.p.) with RAMH ( $10 \mathrm{mg} / \mathrm{kg}$, i.p.) on duration of THLE induced in MES model in male adult mice. Each value represents mean $\pm \operatorname{SEM}(\mathrm{n}=8)$. $* * * P<0.001$ versus saline- and 2 - 18 (7.5 mg)-treated groups. ${ }^{\# P}<0.001$ versus 2 - 18 (7.5 mg)- and 2 - 18 (I5 mg)-treated groups. ${ }^{\$}<0.05$ versus 2 - 18 (30 mg)-treated group.

Abbreviations: MES, maximal electroshock; VPA, valproic acid; i.p., intraperitoneal; RAMH, $R-(\alpha)$-methylhistamine; THLE, tonic hind limb extension; SAL, saline; SEM, standard error of mean.

were observed upon acute systemic injection with 15, 30, and $60 \mathrm{mg} / \mathrm{kg}$ of H3R antagonist 2-18 when compared with saline- or 2-18 (7.5 mg)-treated groups (all $P$-values $<0.001$ ) (Figure 2). Notably, the protection provided by H3R antagonist 2-18 at the higher dose (60 mg/kg, i.p.) was comparable to that provided by the reference drug VPA with $U=28.00$ and $P=0.721$ (Figure 2). Moreover, the reversal of protection provided by $\mathrm{H} 3 \mathrm{R}$ antagonist 2-18 was examined and confirmed by co-injection with the potent and selective CNS-penetrant histamine H3R agonist RAMH (10 mg/kg, i.p.) $15 \mathrm{~min}$ before MES challenge ( $U=50.00 P=0.07$, for the comparison of salinesaline vs 2-18+ RAMH) (Figure 2). Furthermore, RAMH $(10 \mathrm{mg} / \mathrm{kg}$, i.p.) when injected alone did not affect MESinduced convulsions ( $U=46.50$ and $P=0.13$ saline + saline vs saline + RAMH) (Figure 2).

\section{Anticonvulsant effect of $\mathrm{H} 3 \mathrm{R}$ antagonist 2-I 8 in MES-induced convulsion model in female adult mice}

Similarly, the protective effects of acute systemic administration of H3R ligand 2-18 on MES-induced convulsions in female adult mice were examined (Figure 3). The results showed that pretreatment with VPA and H3R antagonist 2-18 $(7.5,15,30$, and $60 \mathrm{mg} / \mathrm{kg}$, i.p.) displayed a significant 


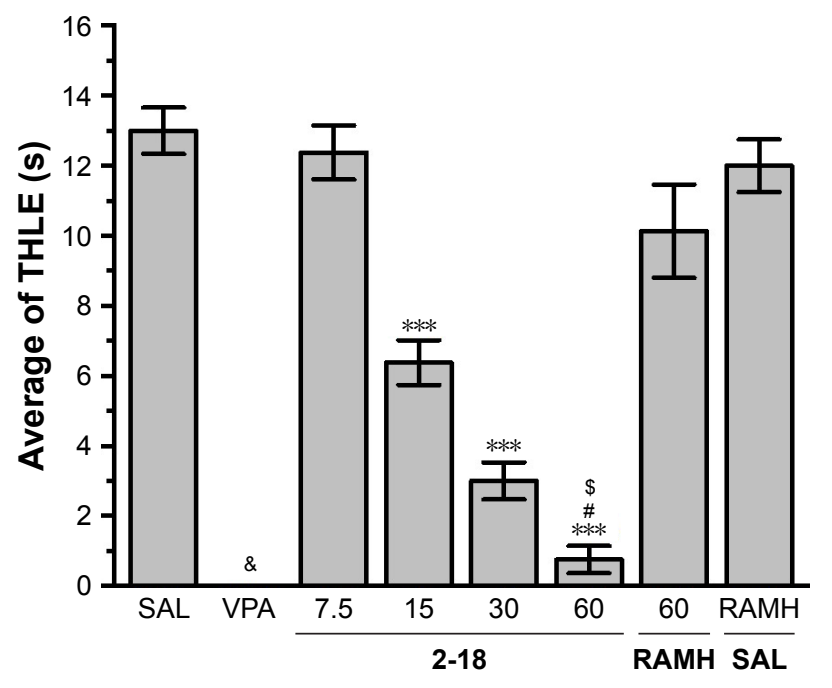

Figure 3 Anticonvulsant effect of acute systemic administration of H3R antagonist 2-I 8 on MES-induced seizure in female adult mice.

Notes: Anticonvulsant effects of VPA (300 mg/kg, i.p.), test compound 2-18 (7.5, 15,30 , and $60 \mathrm{mg} / \mathrm{kg}$, i.p.), and co-injection of test compound 2-18 $(60 \mathrm{mg} / \mathrm{kg}$, i.p.) with RAMH $(10 \mathrm{mg} / \mathrm{kg}$, i.p.) on duration of THLE induced in MES model in female adult mice. Each value represents mean $\pm \operatorname{SEM}(\mathrm{n}=8)$. $* * * P<0.001$ versus saline- and 2-18 (7.5 mg)-treated groups. ${ }^{\#} P<0.001$ versus 2 - 18 (7.5 mg)- and 2-18 (I5 mg)treated groups. ${ }^{\$} P<0.05$ versus 2 - 18 (30 mg)-treated group. ${ }^{8}$ Full protection.

Abbreviations: MES, maximal electroshock; VPA, valproic acid; i.p., intraperitoneal; RAMH, $R$ - $(\alpha)$-methylhistamine; THLE, tonic hind limb extension; SAL, saline; SEM, standard error of mean.

protection against MES-induced convulsions as confirmed by applying Kruskal-Wallis test $\left(H_{(7)}=40.51 ; P<0.001\right)$. Pairwise analysis of variance showed that $\mathrm{H} 3 \mathrm{R}$ antagonist 2-18 at a dose of $60 \mathrm{mg} / \mathrm{kg}$ significantly exhibited the highest protective effect in MES model in female adult mice when compared with the saline- and 2-18 (7.5 $\mathrm{mg})$-treated group with (all $P<0.05$ ) (Figure 3). However, no significant differences were found between 2-18 (60 mg)-treated group and 2-18 (15 mg)- or 2-18 (30 mg)-treated group with $P=0.23$ and $P=0.73$, respectively. Moreover, the results revealed that female adult mice pretreated with $7.5 \mathrm{mg} / \mathrm{kg}$ of $\mathrm{H} 3 \mathrm{R}$ antagonist 2-18 were not protected against MES convulsions when compared with the saline-treated group with $U=29.00$ and $P=0.798$ (Figure 3). Similar to the results observed in male adult mice, the protection provided by H3R antagonist 2-18 at the higher dose (60 mg/kg, i.p.) was comparable to that provided by the reference drug VPA with $U=20.00$ and $P=0.234$ (Figure 3). Moreover, the 2-18 (60 mg)-provided protection was completely abrogated by acute systemic coadministration of the potent and selective CNS-penetrant histamine H3R agonist RAMH ( $10 \mathrm{mg} / \mathrm{kg}$, i.p.) $15 \mathrm{~min}$ before MES challenge ( $U=45.50$ and $P=0.161$, for the comparison of saline + saline vs 2-18 [60 mg] + RAMH) (Figure 3). Analyses of data characterizing the protective effects of RAMH in female mice when injected alone $(10 \mathrm{mg} / \mathrm{kg}$, i.p.; $U=44.00$ and $P=0.234$ saline-saline vs saline-RAMH) yielded results similar to those observed in male mice (Figure 3).

\section{Comparison of H3R antagonist}

2-18-provided anticonvulsant effect in MES-induced convulsion model in male and female adult mice

The influence of the sex on the 2-18-provided anticonvulsant effect was assessed using Mann-Whitney test. Pairwise analyses of the observed results showed that there were no significant differences among tested groups with $U=24.50$ ( $P=0.418), U=31.00(P=0.913), U=31.00(P=0.913), U=19.00$ ( $P=0.168), U=16.00(P=0.084)$, and $U=28.00(P=0.629)$ for saline-, VPA-, 2-18 (7.5 mg)-, 2-18 (15 mg)-, 2-18 (30 mg)-, and 2-18 (60 mg)-treated groups of both sexes (Figure 4).

\section{Results of reproductive studies}

There was no increased incidence of gross morphological anomalies in the treated fetuses of the single- and multipledose groups given i.p. and orally when compared to the control group. The incidence of exencephaly and craniofacial malformations such as mandibular and maxillary hypoplasia, low set microtia, exophthalmia, exomphalos, eye remaining open, posterior bilateral palate, posterior unilateral palate, hydronephrosis, descended kidney, kinky tail, and undescended testis was not significantly different in any of the groups studied (Table 1).

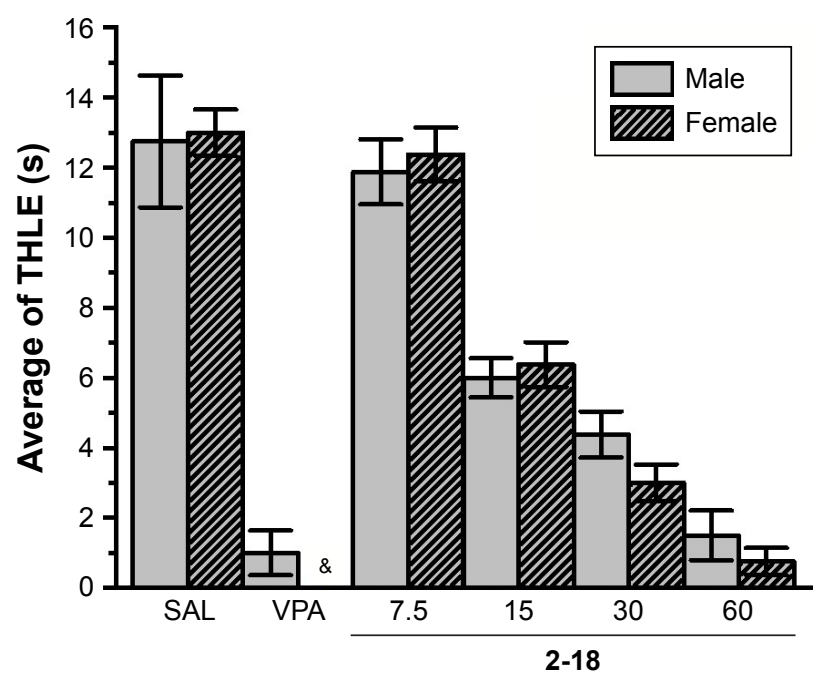

Figure 4 Comparison of dose-dependent anticonvulsant effect of acute systemic administration of H3R antagonist 2-18 on MES-induced seizure in male and female adult mice.

Notes: Each value represents mean $\pm \operatorname{SEM}(n=8)$. ${ }^{\text {FFull }}$ protection.

Abbreviations: MES, maximal electroshock; THLE, tonic hind limb extension; VPA, valproic acid; SAL, saline; SEM, standard error of mean. 
There was no maternal mortality from the doses given. There were no abortions. Food and water consumption was the same in all groups. There was no difference in the numbers of litters or fetuses and placentae in the different groups. There were no differences between the weights of the fetuses and placentae per litter in all groups except in those administered $7.5 \mathrm{mg} / \mathrm{kg}$ of the drug i.p., which for some reason showed a significant reduction in weight $(P<0.05)$. The saline control groups and the treatment groups had the same incidence of resorption and occurrence of intrauterine growth retardation. They did not differ in their mean fetal body weight. There was no dose-dependent reduction in fetal body weight even in the triple-dose groups (Tables 2 and 3).

\section{Skeletal malformations}

\section{Skull defects}

The experimental group skulls were normal in size compared to the controls (Table 4). Some of the treated group vault bases were poorly ossified but not significantly so. Maxilla and mandible were normal as compared to controls except for those in the early organogenesis period treated with low- and medium-dose groups. The supraoccipital bones of 78\%-90\% of the fetuses of the experimental group were at stage 5-6 as compared to $88 \%-90 \%$ control fetuses (Table 4). All fetuses had well-ossified bones. In the whole experiment, we found $0.2 \%$ fetuses that were exencephalic, all having defects of missing bones in the vault of the skull, and hypoplastic basicranial structures, ie, ethmoid, presphenoid, basisphenoid, and basioccipital bones. Axillarymandibular hypoplasia was also present. They also had other skeletal defects of ilium, ischium, and pubis, and malformations of sacral and coccygeal vertebrae. All these were no different in the experimental embryos compared with the controls.

\section{Vertebral defects}

The vertebral column of full term mouse fetuses comprises seven cervical, 13 thoracic, six lumbar, six sacral, and variable number of coccygeal arches. The centra were moderately fewer in number in i.p.-treated GD 8 group. The number

Table 2 Effect of H3R antagonist 2-18 treatment (i.p. or oral) in mouse embryos on GD 8 or 13

\begin{tabular}{|c|c|c|c|c|c|c|}
\hline & \multirow[t]{2}{*}{ Saline control } & \multicolumn{5}{|c|}{ i.p. treatment on GD 8} \\
\hline & & $7.5 \mathrm{mg} / \mathrm{kg}$ & 15 mg/kg & 30 mg/kg & $60 \mathrm{mg} / \mathrm{kg}$ & $15 \mathrm{mg} / \mathrm{kg} \times 3$ dose \\
\hline Number of litters & 8 & 7 & 7 & 7 & 7 & 8 \\
\hline Fetuses/placentae/litter & $10.500 \pm 0.535$ & $10.429 \pm 0.976$ & $10.000 \pm 0.816$ & $10.143 \pm 0.678$ & $9.714 \pm 0.756$ & $10.968 \pm 0.926$ \\
\hline Live fetus/litter & $9.658(91.67)$ & $9.429(90.4 I)$ & $9.143(91.43)$ & $9.429(92.95)$ & $9.000(92.65)$ & $9.875(89.77)$ \\
\hline Resorption/litter & $0.692(6.49)$ & $0.690(10.61)$ & $0.714(7.8 I)$ & $0.787(7.8 \mathrm{I})$ & $0.714(7.94)$ & 0.835 (I I.39) \\
\hline \multicolumn{7}{|l|}{ Fetal weight/litter (g) } \\
\hline$($ Mean \pm SD) & I.269 \pm 0.024 & $1.23 \mathrm{I} \pm 0.025$ & $1.239 \pm 0.036$ & I. $258 \pm 0.027$ & $|.293 \pm 0.03|$ & $1.259 \pm 0.074$ \\
\hline IUGR-ISD & 6/77 (7.79) & $9 / 66(13.64)$ & II/64 (I7.18) & $8 / 66(12.12)$ & $4 / 63(6.35)$ & $9 / 79$ ( I I.39) \\
\hline IUGR-2SD & $3 / 77(3.90)$ & $7 / 66(10.61)$ & $5 / 64(7.8 I)$ & $4 / 66(6.06)$ & $3 / 63(4.76)$ & $8 / 79(10.12)$ \\
\hline \multicolumn{7}{|l|}{ Placental weight/litter (g) } \\
\hline$($ Mean $\pm S D)$ & $0.097 \pm 0.002$ & $0.091 \pm 0.002$ & $0.097 \pm 0.009$ & $0.093 \pm 0.007$ & $0.097 \pm 0.009$ & $0.092 \pm 0.010$ \\
\hline IUGR-ISD & $7 / 77$ (9.09) & $8 / 66(12.12)$ & $9 / 64(14.06)$ & $7 / 66(10.74)$ & $7 / 63($ (II.II) & $10 / 79(12.66)$ \\
\hline \multirow[t]{3}{*}{ IUGR-2SD } & 2/77 (2.59) & $4 / 66(6.06)$ & $5 / 64(7.81)$ & $4 / 66(6.06)$ & $3 / 63(4.76)$ & $5 / 79(6.33)$ \\
\hline & Saline control & \multicolumn{5}{|c|}{ i.p. treatment on GD I3 } \\
\hline & & 7.5 mg/kg & 15 mg/kg & 30 mg/kg & $60 \mathrm{mg} / \mathrm{kg}$ & $15 \mathrm{mg} / \mathrm{kg} \times 3$ dose \\
\hline Number of litters & 7 & 7 & 7 & 7 & 8 & 8 \\
\hline Fetuses/placentae/litter & $9.714 \pm 1.113$ & $10.429 \pm 0.787$ & $10.286 \pm 1.496$ & $10.37| \pm 0.95|$ & $9.500 \pm 0.926$ & $10.000 \pm 1.309$ \\
\hline Live fetus/litter & $9.429(97.06)$ & $9.286(89.04)$ & 9.429 (91.67) & 9.014 (91.89) & $8.875(93.42)$ & $9.000(90.00)$ \\
\hline Resorption/litter & $0.429(4.55)$ & $0.7 \mid 4(12.31)$ & $0.857(12.12)$ & $0.857(8.82)$ & $0.500(7.04)$ & $0.875(\mathrm{II} . \mathrm{II})$ \\
\hline \multicolumn{7}{|l|}{ Fetal weight/litter (g) } \\
\hline$($ Mean \pm SD) & $1.330 \pm 0.062$ & $1.275 \pm 0.049$ & $1.285 \pm 0.062$ & $1.273 \pm 0.055$ & $1.31 \mathrm{I} \pm 0.030$ & $1.287 \pm 0.058$ \\
\hline IUGR-ISD & $6 / 66(9.09)$ & $9 / 65$ (13.85) & $8 / 66(12.12)$ & 8/68 (11.76) & 6/7I (8.45) & II/72 (I5.28) \\
\hline IUGR-2SD & $5 / 66(7.58)$ & $8 / 65(12.30)$ & $10 / 66(15.15)$ & $8 / 68(11.76)$ & 5/7I (7.04) & $9 / 72(12.50)$ \\
\hline \multicolumn{7}{|l|}{ Placental weight/litter (g) } \\
\hline$($ Mean $\pm S D)$ & $0.100 \pm 0.006$ & $0.095 \pm 0.007$ & $0.095 \pm 0.006$ & $0.095 \pm 0.006$ & $0.098 \pm 0.007$ & $0.094 \pm 0.006 *$ \\
\hline IUGR-ISD & $7 / 66(10.60)$ & II/65 (16.92) & $9 / 66(13.63)$ & $9 / 68(13.23)$ & 7/7I (9.86) & I I/72 (I5.28) \\
\hline IUGR-2SD & $5 / 66(7.58)$ & $8 / 65$ (12.30) & 6/66 (9.09) & 8/68 (II.76) & 6/7I (8.45) & $9 / 72(12.50)$ \\
\hline
\end{tabular}

Notes: $* P<0.05$, compared to the controls values (bold value). Numerals in parentheses are percentages.

Abbreviations: i.p., intraperitoneal; GD, gestation day; IUGR, intrauterine growth retardation. 
Table 3 Effect of H3R antagonist 2-I 8 treatment (i.p. or oral) in mouse embryos on GD 8 or I3

\begin{tabular}{|c|c|c|c|c|c|c|}
\hline & \multirow[t]{2}{*}{ Saline control } & \multicolumn{5}{|c|}{ Oral treatment on GD 8} \\
\hline & & $7.5 \mathrm{mg} / \mathrm{kg}$ & $15 \mathrm{mg} / \mathrm{kg}$ & $30 \mathrm{mg} / \mathrm{kg}$ & $60 \mathrm{mg} / \mathrm{kg}$ & $15 \mathrm{mg} / \mathrm{kg} \times 3$ dose \\
\hline Number of litters & 8 & 8 & 8 & 8 & 8 & 8 \\
\hline Fetuses/placentae/litter & $10.500 \pm 0.535$ & $9.875 \pm 0.835$ & $9.250 \pm 0.886$ & $9.250 \pm 0.736$ & $9.875 \pm 0.64 \mid$ & $10.625 \pm 0.744$ \\
\hline Live fetus/litter & 9.658 (91.67) & $9.000(91.14)$ & $8.250(89.19)^{*}$ & $8.375(90.54)$ & $9.250(93.67)$ & 9.625 (90.59) \\
\hline Resorption/litter & $0.692(6.49)$ & $0.875(9.72)$ & $1.000(12.12)$ & $0.835(10.45)$ & $0.625(6.75)$ & $0.875(10.38)$ \\
\hline \multicolumn{7}{|l|}{ Fetal weight/litter (g) } \\
\hline$($ Mean \pm SD) & $1.269 \pm 0.024$ & $1.253 \pm 0.084$ & $1.262 \pm 0.054$ & $1.252 \pm 0.032$ & $1.277 \pm 0.036$ & $1.265 \pm 0.079$ \\
\hline IUGR-ISD & 6/77 (7.79) & $9 / 72(12.50)$ & $7 / 66(10.61)$ & $7 / 67(10.44)$ & $7 / 74(9.46)$ & $8 / 77(10.38)$ \\
\hline IUGR-2SD & $3 / 77(3.90)$ & 6/72 (8.33) & $6 / 66(9.09)$ & $5 / 67(7.46)$ & $4 / 74(5.4 I)$ & 6/77 (7.79) \\
\hline \multicolumn{7}{|l|}{ Placental weight/litter (g) } \\
\hline$($ Mean $\pm S D)$ & $0.097 \pm 0.002$ & $0.095 \pm 0.008$ & $0.096 \pm 0.009$ & $0.093 \pm 0.006$ & $0.094 \pm 0.008$ & $0.094 \pm 0.007$ \\
\hline IUGR-ISD & $7 / 77(9.09)$ & $7 / 72(9.72)$ & $8 / 66(12.12)$ & $8 / 67(11.94)$ & $6 / 74(8.10)$ & $7 / 77(9.09)$ \\
\hline \multirow[t]{3}{*}{ IUGR-2SD } & $2 / 77(2.59)$ & $6 / 72(8.33)^{*}$ & $5 / 66(7.56)$ & $5 / 67(7.46)$ & $4 / 74(5.4 I)$ & $5 / 77(6.49)$ \\
\hline & Saline control & \multicolumn{5}{|c|}{ Oral treatment on GD I3 } \\
\hline & & $7.5 \mathrm{mg} / \mathrm{kg}$ & 15 mg/kg & $30 \mathrm{mg} / \mathrm{kg}$ & $60 \mathrm{mg} / \mathrm{kg}$ & $15 \mathrm{mg} / \mathrm{kg} \times 3$ dose \\
\hline Number of litters & 7 & 8 & 8 & 8 & 8 & 7 \\
\hline Fetuses/placentae/litter & $9.714 \pm 1.113$ & $9.750 \pm 1.035$ & $10.000 \pm 1.195$ & $9.500 \pm 1.069$ & $9.500 \pm 0.926$ & $10.857 \pm 1.345$ \\
\hline Live fetus/litter & $9.429(97.06)$ & $9.000(92.31)$ & $9.250(92.50)$ & $9.125(92.10)$ & $9.000(94.74)$ & $10.143(93.42)$ \\
\hline Resorption/litter & $0.429(4.55)$ & $0.750(8.33)$ & $0.750(8.11)$ & $0.750(8.57)$ & $0.500(5.55)$ & $0.571(7.04)$ \\
\hline \multicolumn{7}{|l|}{ Fetal weight/litter (g) } \\
\hline$($ Mean \pm SD) & $1.330 \pm 0.062$ & $1.26 \mathrm{I} \pm 0.057^{*}$ & $1.282 \pm 0.056$ & $1.273 \pm 0.052$ & $1.301 \pm 0.090$ & $1.273 \pm 0.077$ \\
\hline IUGR-ISD & $6 / 66(9.09)$ & 10/72 (13.88) & $8 / 74(10.8 I)$ & $8 / 70(I I .42)$ & $7 / 72(9.72)$ & I0/7| (|4.08) \\
\hline IUGR-2SD & $5 / 66(7.58)$ & $7 / 72(9.72)$ & $7 / 74(9.46)$ & $6 / 70(8.57)$ & $7 / 72(9.72)$ & $9 / 71$ (12.68) \\
\hline \multicolumn{7}{|l|}{ Placental weight/litter (g) } \\
\hline$($ Mean $\pm S D)$ & $0.100 \pm 0.006$ & $0.093 \pm 0.005 *$ & $0.090 \pm 0.007^{*}$ & $0.094 \pm 0.007$ & $0.094 \pm 0.006$ & $0.089 \pm 0.006 *$ \\
\hline IUGR-ISD & $7 / 66(10.60)$ & II/72 (I5.28) & II/74 (I4.86) & $9 / 70(12.85)$ & $8 / 72(I I . I I)$ & 7/7I (9.86) \\
\hline IUGR-2SD & $5 / 66(7.58)$ & $8 / 72(11.11)$ & $8 / 74(10.8 I)$ & $7 / 70(10.00)$ & $7 / 72(9.72)$ & 9/7I (12.68) \\
\hline
\end{tabular}

Notes: $* P<0.05$, compared to the controls values (bold values). Numerals in parentheses are percentages.

Abbreviations: i.p., intraperitoneal; GD, gestation day; IUGR, intrauterine growth retardation.

of unossified/hypoplastic body was slightly increased in the early i.p.-induced and late gestation oral-treated groups but did not differ significantly from the controls (Table 5). Hemivertebrae and fusion of the centra in the thoracic, lumbar, and sacral segments were not observed. Hypoplastic or poor ossification of the caudal vertebrae number was slightly augmented in the experimental groups. There was a reduction in the number of coccygeal vertebral bodies observed in GD 8-treated fetuses.

\section{Rib defects}

In both control and experimental fetuses, 13 pairs of thoracic ribs were observed giving a $2.6 \%$ incidence of cervical and lumbar ribs. The cervical ribs were attached to the seventh cervical vertebra and ended free anteriorly and were the first thoracic ribs. In the treated groups, cervical ribs were moderately increased in number particularly in early gestation i.p.-induced group (Table 6). The lumbar ribs attached with the first lumbar vertebra were shorter than the last pair of the thoracic ribs. Incidence of lumbar ribs in the drug-treated group was not significantly different when compared to controls. There was no fusion of ribs, reduction in number and size, and splitting and forking of ribs in both control and treated groups.

\section{Sternal defects}

The sternum of the control fetuses consisted of seven sternebrae; the fifth sternebrum was moderately smaller in the late gestation-treated embryos. In about $97 \%-100 \%$ of fetuses, there were seven pairs of ribs. Absence or hypoplasia of the fifth sternebrum in the treated groups did not significantly differ from the controls (Table 6). We did not observe any malalignment, hemilateral or unilateral agenesis, scrambling, or fusion, but there were a few cases of bifid sternebrae in $30 \mathrm{mg} / \mathrm{kg}$ i.p.-treated group embryos.

\section{Limb defects}

There were no significant differences between the stages of limb development in any of the drug-administered mice fetuses when compared to the saline-administered mice 
Table 4 H3R antagonist 2-18-induced skull abnormalities in mouse fetuses

\begin{tabular}{|c|c|c|c|c|c|c|c|c|c|c|c|}
\hline & \multirow[t]{2}{*}{ Saline } & \multicolumn{5}{|c|}{ GD 8 (i.p. treated) } & \multicolumn{5}{|c|}{ GD 8 (orally treated) } \\
\hline & & $7.5 \mathrm{mg}$ & $15 \mathrm{mg}$ & $30 \mathrm{mg}$ & $60 \mathrm{mg}$ & $15 \times 3 \mathrm{mg}$ & $7.5 \mathrm{mg}$ & 15 mg & $30 \mathrm{mg}$ & $60 \mathrm{mg}$ & $15 \times 3 \mathrm{mg}$ \\
\hline $\begin{array}{l}\text { No of skeletons } \\
\text { examined }\end{array}$ & 42 & 38 & 37 & 40 & 38 & 36 & 37 & 39 & 41 & 38 & 42 \\
\hline \multicolumn{12}{|l|}{ Hypoplastic } \\
\hline Mandible & $2(4.8)$ & $3(7.9)$ & $2(5.4)$ & $4(10.0)^{*}$ & $2(5.3)$ & $3(8.3)$ & $2(5.4)$ & $2(5.1)$ & $2(4.9)$ & $2(5.3)$ & $3(7.1)$ \\
\hline Maxilla & $2(4.8)$ & $3(7.9)$ & $2(5.4)$ & $4(10.0)^{*}$ & $2(5.3)$ & $3(8.3)$ & $2(5.4)$ & $2(5.1)$ & $2(4.9)$ & $2(5.3)$ & $3(7.1)$ \\
\hline Zygomatic & I (2.4) & $2(5.3)$ & I (2.7) & I (2.5) & I (2.6) & I (2.8) & $2(5.4)$ & I (2.6) & $2(4.9)$ & I (2.6) & I (2.4) \\
\hline Nasal & I (2.4) & $2(5.3)$ & I (2.7) & I (2.5) & I (2.6) & $2(5.6)$ & I (2.7) & I (2.6) & $2(4.9)$ & I (2.6) & $2(4.8)$ \\
\hline Frontal & $2(4.8)$ & $3(7.9)$ & $2(5.4)$ & $2(5.0)$ & $2(5.3)$ & $2(5.6)$ & $3(8.1)$ & $3(7.7)$ & $2(4.9)$ & $2(5.3)$ & $2(4.8)$ \\
\hline Parietal & I (2.4) & $2(5.3)$ & $2(5.4)$ & $2(5.0)$ & I (2.6) & I (2.8) & $2(5.4)$ & $2(5.1)$ & $2(4.9)$ & I (2.6) & I (2.4) \\
\hline Inter parietal & I (2.4) & $2(5.3)$ & I (2.7) & I (2.5) & I (2.6) & I (2.8) & $2(5.4)$ & I (2.6) & I (2.4) & I (2.6) & I (2.4) \\
\hline Exoccipital & 0 & $I(2.6)$ & I (2.7) & I (2.5) & I (2.6) & I (2.8) & I (2.7) & I (2.6) & I (2.4) & I (2.6) & I (2.4) \\
\hline Ethmoid & $2(4.8)$ & $3(7.9)$ & $2(5.4)$ & $2(5.0)$ & $2(5.3)$ & $3(8.3)$ & $2(5.4)$ & $3(7.7)$ & $2(4.9)$ & $2(5.3)$ & $3(7.1)$ \\
\hline Presphenoid & I (2.4) & $2(5.3)$ & $2(5.4)$ & I (2.5) & I (2.6) & $2(5.6)$ & $2(5.4)$ & $2(5.1)$ & I (2.4) & I (2.6) & I (2.4) \\
\hline Basis sphenoid & I (2.4) & $2(5.3)$ & $2(5.4)$ & I (2.5) & I (2.6) & $2(5.6)$ & $2(5.4)$ & I (2.6) & I (2.4) & I (2.6) & $2(4.8)$ \\
\hline Basioccipital & I (2.4) & $2(5.3)$ & $2(5.4)$ & I (2.5) & I (2.6) & I (2.8) & $2(5.4)$ & I (2.6) & I (2.4) & I (2.6) & I (2.4) \\
\hline Tympanic ring & I (2.4) & $2(5.3)$ & $2(5.4)$ & $2(5.0)$ & I (2.6) & I (2.8) & $2(5.4)$ & $2(5.1)$ & I (2.4) & I (2.6) & I (2.4) \\
\hline Hyoid & I (2.4) & $2(5.3)$ & $2(5.4)$ & $2(5.0)$ & I (2.6) & $2(5.6)$ & $2(5.4)$ & $2(5.1)$ & I (2.4) & I (2.6) & $2(4.8)$ \\
\hline \multicolumn{12}{|c|}{ Supraoccipital - stage } \\
\hline $1-4$ & $5(11.9)$ & $7(18.4)$ & $9(24.3)^{*}$ & $6(15.0)$ & $5(13.2)$ & $6(16.7)$ & $7(18.9)$ & $7(17.9)$ & $6(14.6)$ & $4(10.5)$ & $7(16.7)$ \\
\hline $5-6$ & $37(88.1)$ & $31(81.6)$ & $28(75.7)$ & $34(85.0)$ & $33(86.8)$ & $30(83.3)$ & $30(8 I .1)$ & $32(82.1)$ & $35(85.4)$ & $34(89.5)$ & $35(83.3)$ \\
\hline Hypoplastic & $4(9.5)$ & $6(15.8)$ & $6(16.2)$ & $5(12.5)$ & $4(10.5)$ & $5(13.9)$ & $6(16.2)$ & $5(12.8)$ & $4(9.8)$ & $3(7.9)$ & $4(9.5)$ \\
\hline \multicolumn{12}{|l|}{ Ossicle } \\
\hline $0-1$ & $2(4.8)$ & $3(7.9)$ & $2(5.4)$ & $3(7.5)$ & $2(5.3)$ & $3(8.3)$ & $3(8.1)$ & $3(7.7)$ & $3(7.3)$ & I (2.6) & $4(9.5)$ \\
\hline 2 & 39 (92.9) & $35(92.1)$ & 34 (9l.9) & $35(87.5)$ & $34(89.5)$ & $33(91.7)$ & 34 (91.9) & $35(89.7)$ & $37(90.2)$ & 35 & $37(88.1)$ \\
\hline \multirow[t]{3}{*}{3} & I (2.4) & 0 & I (2.7) & $2(5.0)$ & $2(5.3)$ & 0 & 0 & I (2.6) & I (2.4) & $2(5.3)$ & I (2.4) \\
\hline & Saline & \multicolumn{5}{|c|}{ GD I3 (i.p. treated) } & \multicolumn{5}{|c|}{ GD I3 (orally treated) } \\
\hline & & $7.5 \mathrm{mg}$ & $15 \mathrm{mg}$ & $30 \mathrm{mg}$ & $60 \mathrm{mg}$ & $15 \times 3 \mathrm{mg}$ & $7.5 \mathrm{mg}$ & $15 \mathrm{mg}$ & $30 \mathrm{mg}$ & $60 \mathrm{mg}$ & $15 \times 3 \mathrm{mg}$ \\
\hline $\begin{array}{l}\text { No of skeletons } \\
\text { examined }\end{array}$ & 39 & 40 & 42 & 36 & 40 & 38 & 38 & 43 & 41 & 38 & 37 \\
\hline \multicolumn{12}{|l|}{ Hypoplastic } \\
\hline Mandible & $2(5.1)$ & $3(7.5)$ & $3(7.1)$ & $2(5.6)$ & $2(5.0)$ & $3(7.9)$ & $3(7.9)$ & $3(7.0)$ & $3(7.3)$ & $2(5.3)$ & $3(8.1)$ \\
\hline Maxilla & $2(5.1)$ & $3(7.5)$ & $3(7.1)$ & $2(5.6)$ & $2(5.0)$ & $3(7.9)$ & $5(13.2)^{*}$ & $2(4.7)$ & $2(4.9)$ & $2(5.3)$ & $3(8.1)$ \\
\hline Zygomatic & I (2.6) & $\mathrm{I}(2.5)$ & $2(4.8)$ & $\mathrm{I}(2.8)$ & $\mathrm{I}(2.5)$ & $I(2.6)$ & $2(5.3)$ & $\mathrm{I}(2.3)$ & $2(4.9)$ & I (2.6) & I (2.7) \\
\hline Nasal & I (2.6) & $2(5.0)$ & $2(4.8)$ & $\mathrm{I}(2.8)$ & $\mathrm{I}(2.5)$ & $2(5.3)$ & $2(5.3)$ & $2(4.7)$ & $2(4.9)$ & I (2.6) & $2(5.4)$ \\
\hline Frontal & $2(5.1)$ & $3(7.5)$ & $3(7.1)$ & $3(8.3)$ & $2(5.0)$ & $2(5.3)$ & $3(7.9)$ & $3(7.0)$ & $2(4.9)$ & $2(5.3)$ & $2(5.4)$ \\
\hline Parietal & I (2.6) & $2(5.0)$ & $2(4.8)$ & $2(5.6)$ & I (2.5) & $2(5.3)$ & $2(5.3)$ & $2(4.7)$ & $2(4.9)$ & I (2.6) & I (2.7) \\
\hline Inter parietal & I (2.6) & $2(5.0)$ & $2(4.8)$ & I (2.8) & I (2.5) & $2(5.3)$ & $2(5.3)$ & $2(4.7)$ & I (2.4) & I (2.6) & $2(5.4)$ \\
\hline Exoccipital & I (2.6) & $2(5.0)$ & $2(4.8)$ & I (2.8) & I (2.5) & I (2.6) & I (2.6) & I (2.3) & I (2.4) & I (2.6) & $2(5.4)$ \\
\hline Ethmoid & I (2.6) & $2(5.0)$ & $3(7.1)$ & $2(5.6)$ & $2(5.0)$ & $3(7.9)$ & $2(5.3)$ & $3(7.0)$ & $2(4.9)$ & $2(5.3)$ & $3(8.1)$ \\
\hline Presphenoid & I (2.6) & $2(5.0)$ & $2(4.8)$ & I (2.8) & I (2.5) & $2(5.3)$ & $2(5.3)$ & $2(4.7)$ & I (2.4) & I (2.6) & I (2.7) \\
\hline Basis sphenoid & I (2.6) & $2(5.0)$ & $2(4.8)$ & I (2.8) & I (2.5) & $2(5.3)$ & $2(5.3)$ & I (2.3) & $2(4.9)$ & I (2.6) & $2(5.4)$ \\
\hline Basioccipital & I (2.6) & $2(5.0)$ & $2(4.8)$ & I (2.8) & I (2.5) & I (2.6) & $2(5.3)$ & I (2.3) & I (2.4) & I (2.6) & I (2.7) \\
\hline Tympanic ring & I (2.6) & $2(5.0)$ & $2(4.8)$ & $2(5.6)$ & I (2.5) & I (2.6) & $2(5.3)$ & $2(4.7)$ & $2(4.9)$ & $2(5.3)$ & I (2.7) \\
\hline Hyoid & $2(5.1)$ & $2(5.0)$ & $2(4.8)$ & $2(5.6)$ & I (2.5) & $2(5.3)$ & $2(5.3)$ & $2(4.7)$ & I (2.4) & I (2.6) & $2(5.4)$ \\
\hline \multicolumn{12}{|c|}{ Supraoccipital - stage } \\
\hline $1-4$ & $4(10.3)$ & $9(22.5)^{*}$ & $8(19.0)$ & $6(16.7)$ & $5(12.5)$ & $6(15.8)$ & $6(15.8)$ & $7(16.3)$ & $6(14.6)$ & $4(10.5)$ & $9(24.3)^{*}$ \\
\hline $5-6$ & $35(89.7)$ & 31 (77.5) & $34(81.0)$ & $30(83.3)$ & $35(87.5)$ & $32(84.2)$ & $32(84.2)$ & $36(83.7)$ & $35(85.4)$ & $34(89.5)$ & $35(94.6)$ \\
\hline Hypoplastic & $3(7.7)$ & $5(12.5)$ & $5(11.9)$ & $5(13.9)$ & $3(7.5)$ & $5(13.2)$ & $5(13.2)$ & $5(11.6)$ & $4(9.8)$ & $3(7.9)$ & $4(10.8)$ \\
\hline \multicolumn{12}{|l|}{ Ossicle } \\
\hline $0-1$ & $2(5.1)$ & $4(10.0)$ & $4(9.5)$ & $3(8.3)$ & $2(5.0)$ & $3(7.9)$ & $4(10.5)$ & $4(9.3)$ & $3(7.3)$ & I (2.6) & $3(8.1)$ \\
\hline 2 & $36(92.3)$ & $36(90.0)$ & $38(90.5)$ & $33(91.7)$ & $37(92.5)$ & $35(92.1)$ & $34(89.5)$ & $38(88.4)$ & 37 & $35(92.1)$ & $33(89.2)$ \\
\hline 3 & I (2.6) & 0 & 0 & 0 & I (2.5) & 0 & 0 & I (2.3) & I (2.4) & $2(5.3)$ & I (2.7) \\
\hline
\end{tabular}

Notes: Numerals in parentheses are percentages; ${ }^{*} P<0.05$, compared to the control values (bold values).

Abbreviations: i.p., intraperitoneal; GD, gestation day. 


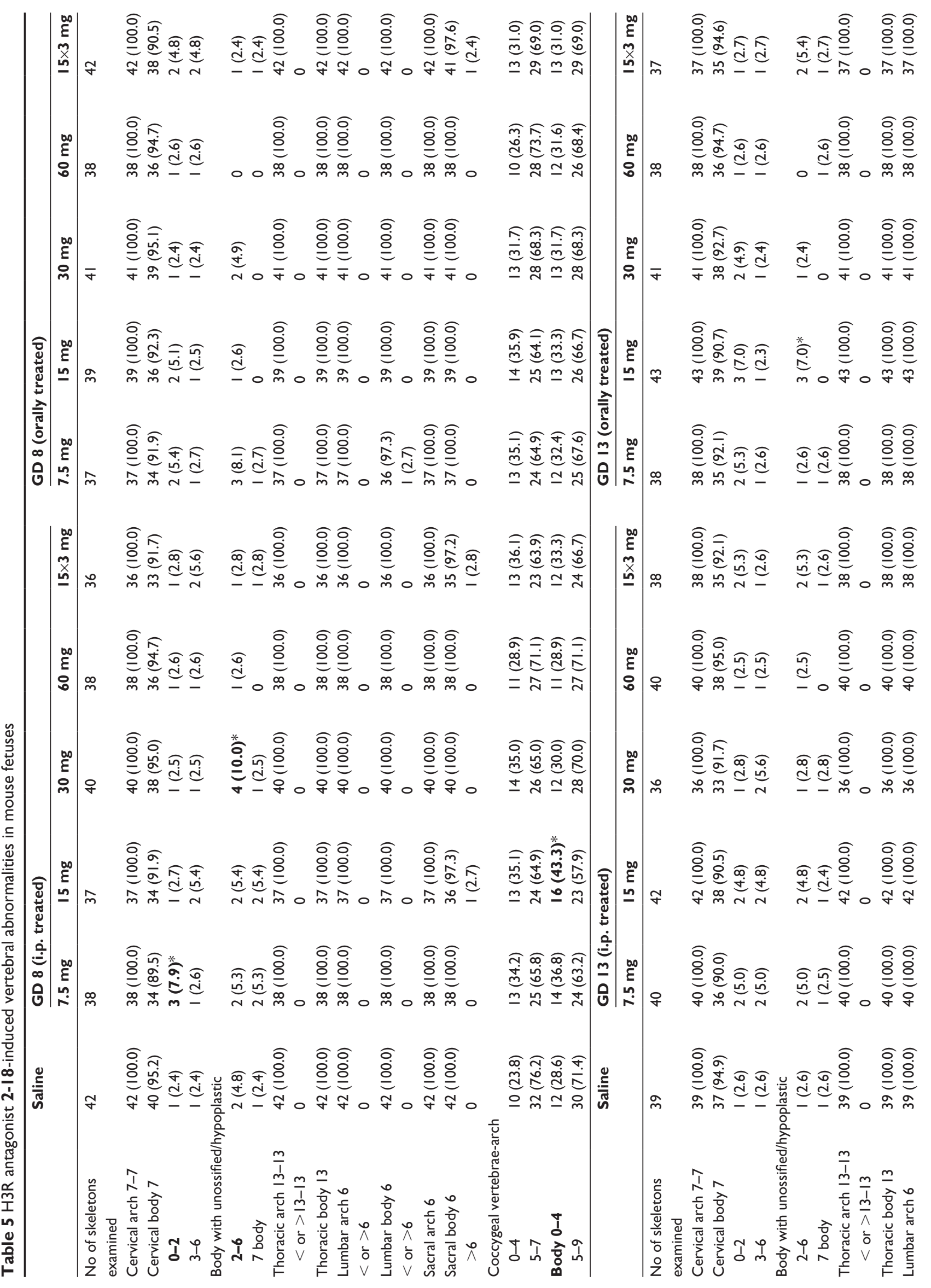




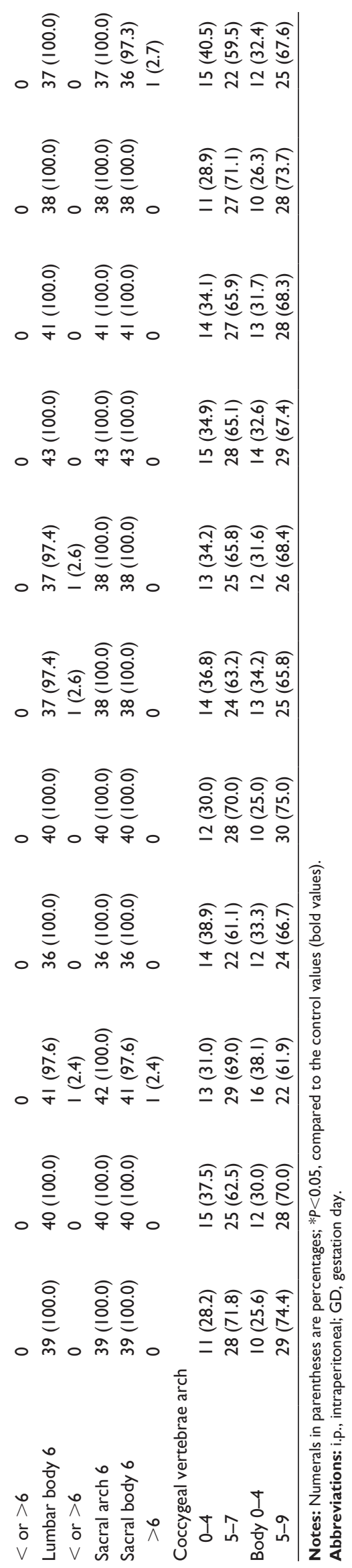

fetuses (Table 7). However, in the eight GD, orally treated mice fetuses with the three-dose regimen, there were significantly more 2-foot tarsals than the control fetuses. In addition, there was a significantly higher number of mice fetuses with $0-4$ metatarsals on day 13 orally treated experimental group than there were in controls. All others were similar in all groups of mice.

In short, there were no significant differences in skeletal anomalies, vertebral defects, skull defects, rib defects, sternal defects, or limb defects in all the groups of mice studied. There were no anomalies of the internal organs.

\section{Discussion}

The results in the MES model showed that H3R antagonist 2-18 provided the most encouraging protection against MESinduced convulsions when animals were pretreated with $60 \mathrm{mg} / \mathrm{kg}$ i.p., as compared with the saline-treated or lower dosed groups (Figures 1-3). Consequently, the observed results revealed a dose-response relationship of the protection provided for H3R antagonist 2-18 in the MES-induced convulsions in adult mice of both sexes (Figures 1 and 2). Notably, the protective activity of H3R antagonist 2-18 $(60 \mathrm{mg} / \mathrm{kg}$, i.p.) was similar to that observed in the group pretreated with the reference AED VPA (500 mg/kg, i.p.) (Figures 1 and 2). The latter results are in agreement with recent preclinical outcomes that showed a dose-dependent anticonvulsant activity of numerous H3R antagonists in MES-induced convulsions in several animal models and of PIT in a photosensitivity seizure model in adult patients. ${ }^{10-12,14-16,28}$ An additional experiment in the present study indicated that the protection observed for H3R antagonist 2-18 was reversed when animals were co-injected with the CNS-penetrant histamine H3R agonist RAMH (10 mg/kg i.p.) (Figure 1). Interestingly, RAMH $(10 \mathrm{mg} / \mathrm{kg})$ injected alone showed neither a protective nor an epileptogenic activity in animals challenged by the MESinduced convulsion (Figures 1 and 2). These results propose that the protective activity of the H3R antagonist 2-18 in the MES-induced convulsion is facilitated, at least to some extent, through H3R blockade, and are in agreement with the previously observed protective efficacies for numerous imidazole as well as non-imidazole-based H3R antagonists. ${ }^{10-14,16,40}$ Accordingly, H3Rs are autoreceptors located on presynaptic histaminergic terminals with an inhibitory effect on the biosynthesis and release of histamine into histaminergic synaptic gap. ${ }^{12}$ Therefore, H3R blockade by selective antagonists, such as compound $\mathbf{2 - 1 8}$, would produce an increased neuronal release of central histamine, providing the protective effect in the MES-induced convulsion mode in mice. 


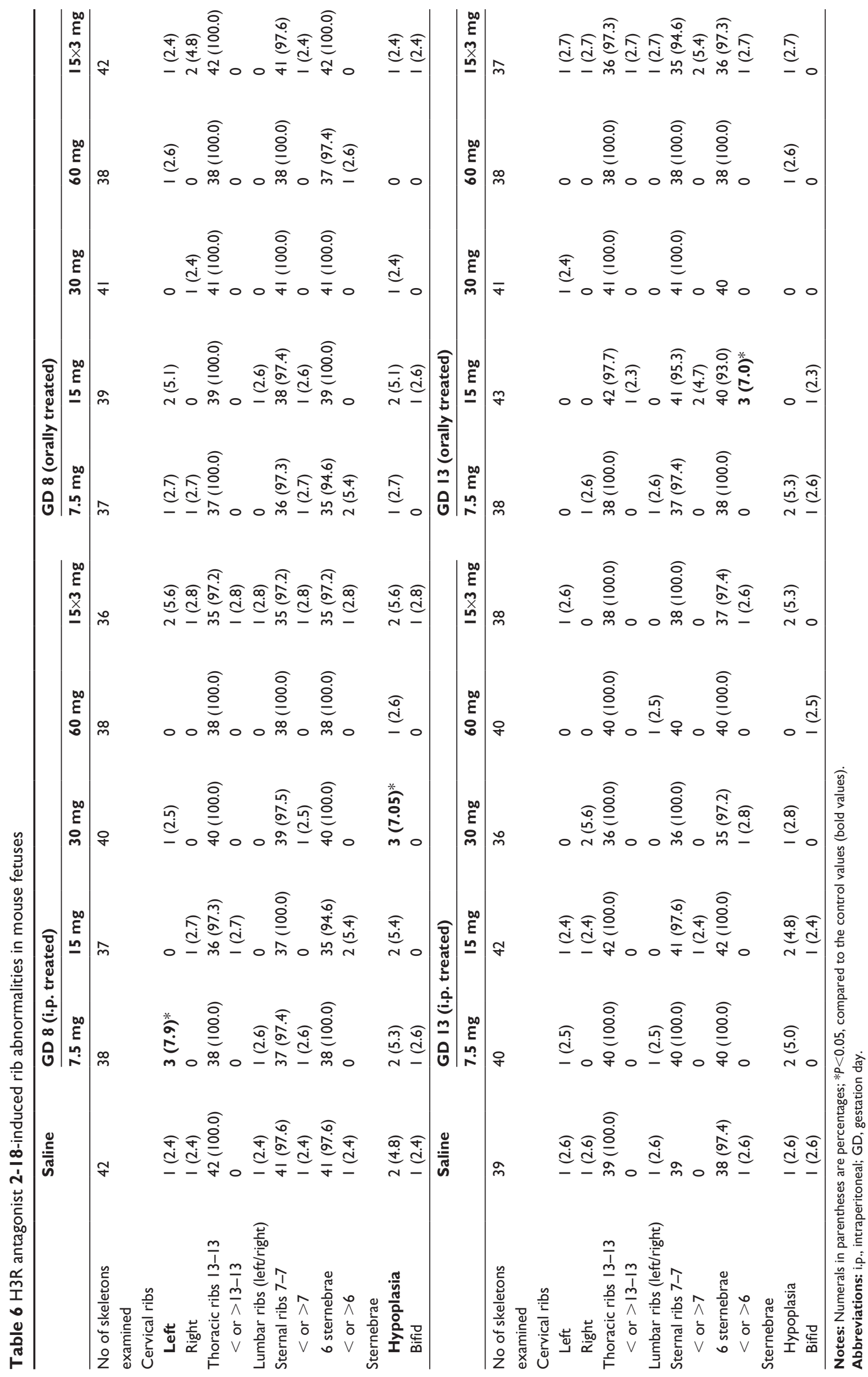


Table $7 \mathrm{H} 3 \mathrm{R}$ antagonist 2-18-induced limb abnormalities in mouse fetuses

\begin{tabular}{|c|c|c|c|c|c|c|c|c|c|c|c|}
\hline & \multirow[t]{2}{*}{ Saline } & \multicolumn{5}{|c|}{ GD 8 (i.p. treated) } & \multicolumn{5}{|c|}{ GD 8 (orally treated) } \\
\hline & & $7.5 \mathrm{mg}$ & 15 mg & $30 \mathrm{mg}$ & $60 \mathrm{mg}$ & $15 \times 3 \mathrm{mg}$ & $7.5 \mathrm{mg}$ & $15 \mathrm{mg}$ & $30 \mathrm{mg}$ & $60 \mathrm{mg}$ & $15 \times 3 \mathrm{mg}$ \\
\hline $\begin{array}{l}\text { No of skeletons } \\
\text { examined }\end{array}$ & 42 & 38 & 37 & 40 & 38 & 36 & 37 & 39 & 41 & 38 & 42 \\
\hline \multicolumn{12}{|c|}{ Hand - metacarpals } \\
\hline $0-3$ & $2(4.8)$ & $3(7.3)$ & $2(5.4)$ & $2(5.0)$ & $2(5.3)$ & $3(8.3)$ & $2(5.4)$ & $2(5.1)$ & $2(4.9)$ & $2(5.3)$ & $3(7.1)$ \\
\hline $4-5$ & $40(95.2)$ & $35(92.1)$ & $35(94.6)$ & $38(95.0)$ & $36(94.7)$ & $33(91.7)$ & $35(94.6)$ & $37(94.9)$ & $39(95.1)$ & $36(94.7)$ & $39(92.9)$ \\
\hline Нуро & $2(4.8)$ & $4(10.5)$ & $5(13.5)^{*}$ & $4(10.0)$ & $2(5.3)$ & $3(8.3)$ & $3(8.1)$ & $4(10.3)$ & $4(9.8)$ & $2(5.3)$ & $4(9.5)$ \\
\hline \multicolumn{12}{|l|}{ Phalanges } \\
\hline $0-5$ & $3(7.1)$ & $3(7.3)$ & $3(8.1)$ & $4(10.0)$ & $2(5.3)$ & $3(8.3)$ & $3(8.1)$ & $3(7.7)$ & $5(12.2)$ & $3(7.9)$ & $3(7.1)$ \\
\hline $6-10$ & $5(11.9)$ & $6(15.8)$ & $6(16.2)$ & $7(17.5)$ & $5(13.2)$ & $6(16.7)$ & $4(10.8)$ & $4(10.3)$ & $4(9.8)$ & $4(10.5)$ & $5(11.9)$ \\
\hline $11-12$ & $34(81.0)$ & $29(76.3)$ & $28(75.7)$ & $29(72.5)$ & $31(81.6)$ & $27(75.0)$ & $30(8 I . I)$ & $32(82.1)$ & $32(78.0)$ & $3 \mid(8 I .5)$ & $33(78.6)$ \\
\hline \multicolumn{12}{|l|}{ Foot - tarsals } \\
\hline 0 & $8(19.0)$ & $8(21.1)$ & $8(21.6)$ & $9(22.5)$ & $6(15.8)$ & 7 (19.4) & $8(21.6)$ & $8(20.5)$ & $8(19.5)$ & $6(15.8)$ & $10(23.8)$ \\
\hline 1 & $28(66.7)$ & $25(65.8)$ & $24(64.9)$ & $25(62.5)$ & $25(65.8)$ & $24(66.7)$ & $25(67.6)$ & $25(64.1)$ & $28(68.3)$ & $26(68.4)$ & $29(69.0)$ \\
\hline 2 & $6(14.3)$ & $5(13.2)$ & $5(13.5)$ & $6(15.0)$ & $7(18.4)$ & $5(13.9)$ & $6(16.2)$ & $6(15.4)$ & $5(12.2)$ & $6(15.8)$ & $3(7.1)^{*}$ \\
\hline \multicolumn{12}{|l|}{ Metatarsals } \\
\hline $0-4$ & $2(4.8)$ & $3(7.9)$ & $2(5.4)$ & $4(10.0)$ & $3(7.9)$ & $3(8.3)$ & $3(8.1)$ & $2(5.1)$ & $3(7.3)$ & $2(5.3)$ & $3(7.1)$ \\
\hline 5 & $40(95.2)$ & $35(92.1)$ & $35(94.6)$ & $36(90.0)$ & $35(92.1)$ & 33 (9l.7) & 34 (91.9) & 37 (94.3) & $39(95.1)$ & $36(94.7)$ & 39 (92.9) \\
\hline \multicolumn{12}{|l|}{ Phalanges } \\
\hline $0-5$ & $2(4.8)$ & $4(10.5)$ & $3(8.1)$ & $3(7.5)$ & $3(7.9)$ & $4(I I .0)$ & $3(8.1)$ & $4(10.3)$ & $4(9.8)$ & $3(7.9)$ & $4(9.5)$ \\
\hline $6-10$ & $21(50.0)$ & $21(55.3)$ & $19(51.4)$ & $18(45.0)$ & $22(57.9)$ & $19(52.8)$ & $20(54.1)$ & $21(53.8)$ & $20(48.8)$ & $18(47.4)$ & $22(52.4)$ \\
\hline \multirow[t]{3}{*}{$11-14$} & $19(45.2)$ & $13(34.2)$ & $15(40.5)$ & $17(42.5)$ & $13(34.2)$ & $13(36.1)$ & $14(37.8)$ & 14 (35.9) & $17(41.5)$ & $17(44.7)$ & $16(38.1)$ \\
\hline & Saline & \multicolumn{5}{|c|}{ GD I3 (i.p. treated) } & \multicolumn{5}{|c|}{ GD I3 (orally treated) } \\
\hline & & $7.5 \mathrm{mg}$ & $15 \mathrm{mg}$ & $30 \mathrm{mg}$ & $60 \mathrm{mg}$ & $15 \times 3 \mathrm{mg}$ & $7.5 \mathrm{mg}$ & $15 \mathrm{mg}$ & $30 \mathrm{mg}$ & $60 \mathrm{mg}$ & $15 \times 3 \mathrm{mg}$ \\
\hline $\begin{array}{l}\text { No of skeletons } \\
\text { examined }\end{array}$ & 39 & 40 & 42 & 36 & 40 & 38 & 38 & 43 & 41 & 38 & 37 \\
\hline \multicolumn{12}{|c|}{ Hand - metacarpals } \\
\hline $0-3$ & $2(5.1)$ & $3(7.5)$ & $4(9.5)$ & $2(5.6)$ & $2(5.0)$ & $3(7.9)$ & $3(7.9)$ & $4(9.3)$ & $4(9.8)$ & $2(5.3)$ & $2(5.4)$ \\
\hline 4-5 & $37(94.9)$ & $36(90.0)$ & $38(90.5)$ & $34(94.4)$ & $38(95.0)$ & $35(92.1)$ & $35(92.1)$ & $39(90.7)$ & $37(90.2)$ & $36(94.7)$ & $35(94.6)$ \\
\hline Нуро & $2(5.1)$ & $4(10.0)$ & $4(9.5)$ & $3(8.3)$ & $3(7.5)$ & $3(7.9)$ & $3(7.9)$ & $4(9.3)$ & $4(9.8)$ & $3(7.9)$ & $3(8.1)$ \\
\hline \multicolumn{12}{|l|}{ Phalanges } \\
\hline $0-5$ & $2(5.1)$ & $3(7.5)$ & $4(9.5)$ & $3(8.3)$ & $2(5.0)$ & $2(5.3)$ & $2(5.3)$ & $4(9.3)$ & $3(7.3)$ & $3(7.9)$ & $2(5.4)$ \\
\hline $6-10$ & $6(15.4)$ & $7(17.5)$ & $9(21.4)$ & $6(16.7)$ & $7(17.5)$ & $7(18.4)$ & $5(13.2)$ & $8(18.60)$ & $7(17.1)$ & $5(13.2)$ & $5(13.5)$ \\
\hline $11-12$ & $31(79.5)$ & $30(75.0)$ & $29(69.0)$ & $27(75.0)$ & 31 (77.5) & $29(76.3)$ & 31 (8I.6) & $31(72.1)$ & $31(75.6)$ & 30 (78.9) & $30(81.1)$ \\
\hline \multicolumn{12}{|l|}{ Foot - tarsals } \\
\hline 0 & $5(12.8)$ & $6(15.0)$ & 9 (2 I.4)* & $6(16.7)$ & $5(12.5)$ & $5(13.2)$ & $5(13.2)$ & $8(18.6)$ & $5(12.2)$ & $4(10.5)$ & $6(16.2)$ \\
\hline I & $26(66.7)$ & $27(67.5)$ & $25(59.5)$ & $27(75.0)$ & $29(72.5)$ & $28(73.7)$ & 27 (7I.I) & $28(65.1)$ & $29(70.7)$ & $28(73.7)$ & $25(67.6)$ \\
\hline 2 & $8(20.5)$ & $7(17.5)$ & $8(19.0)$ & $6(16.7)$ & $6(15.0)$ & $5(13.2)$ & $6(15.8)$ & $7(16.3)$ & $7(17.1)$ & $6(15.8)$ & $6(16.2)$ \\
\hline \multicolumn{12}{|l|}{ Metatarsals } \\
\hline $0-4$ & $2(5.1)$ & $3(7.5)$ & $4(9.5)$ & $3(8.3)$ & $3(7.5)$ & 3 (7.9) & $3(7.9)$ & $5(11.6)$ & $4(9.8)$ & $3(7.9)$ & $5(13.5)^{*}$ \\
\hline 5 & $37(94.9)$ & $37(92.5)$ & $38(90.5)$ & 33 (91.7) & $37(92.5)$ & $35(92.1)$ & $35(92.1)$ & $38(88.4)$ & $37(90.2)$ & $36(94.7)$ & $32(86.5)$ \\
\hline \multicolumn{12}{|l|}{ Phalanges } \\
\hline $0-5$ & $3(7.7)$ & $4(10.0)$ & $5(11.9)$ & $4(1 \mathrm{I} .1)$ & $3(7.5)$ & $4(10.5)$ & $4(10.5)$ & 5 (II.6) & $5(12.2)$ & $3(7.9)$ & $3(8.1)$ \\
\hline $6-10$ & $19(48.7)$ & $20(50.0)$ & $21(50.0)$ & $19(52.8)$ & $18(45.0)$ & 17 (44.7) & 17 (44.7) & $22(5 \mid .2)$ & $18(43.9)$ & $20(52.6)$ & I 8 (48.6) \\
\hline $11-14$ & $17(43.6)$ & $16(40.0)$ & $16(38.1)$ & $13(36.1)$ & $19(47.5)$ & 17 (44.7) & 17 (44.7) & $16(37.2)$ & 18 (43.9) & 17 (44.7) & $16(43.2)$ \\
\hline
\end{tabular}

Notes: Numerals in parentheses are percentages; $* P<0.05$, compared to the control values.

Abbreviations: i.p., intraperitoneal; GD, gestation day.

Importantly, comparable effects of imidazole-based as well as non-imidazole-based H3R antagonists were previously described to be abrogated by either H3R agonists or CNSpenetrant H1R or H2R antagonists, signifying an important role of the H3R antagonism-released histamine. ${ }^{10,14,16,40,41}$ On the other hand, no significant differences were observed for the reference drug VPA (500 mg/kg, i.p.) and for all tested doses of the H3R antagonist 2-18 (7.5-60 mg/kg, i.p.) in both sexes of adult mice (Figure 4). The latter results are in disagreement with previous studies in which certain differences in seizure susceptibility were found between both sexes due to differences in levels of steroids and steroidal derivatives, eg, $3 \alpha$-hydroxylated pregnane steroids, capable of interacting with GABA receptor complex, and therefore decreasing seizure susceptibility in female adult mice. ${ }^{42-45}$ In a further set of experiments, we administered various doses 
of H3R antagonist 2-18 to groups of mice on GDs 8 and 13 and found no difference in the abnormalities that occurred in the fetuses. All AEDs including the third-generation AEDs given to pregnant women have been shown to have deleterious effects on fetuses in numerous studies from all over the world. ${ }^{46-51}$ These effects could result in fetal loss, perinatal death, congenital malformations, hemorrhage, developmental delay, low birth weight, and other serious effects. Epileptic women have no choice but to continue to take AEDs during pregnancy. It is therefore important to develop a therapeutic agent that has a good seizure control and at the same time has a very low risk of side effects in the woman and in the fetus. The present compound, namely the H3R antagonist 2-18, seems to fulfill both criteria and is a promising AED for use during pregnancy in the lowest doses that manage to control the epileptic fits. The doses of H3R antagonist 2-18 used in the present study succeeded in controlling the fits and were not maternally toxic, as the food and water consumed by the mice were not affected. The mice also gained weight normally. These doses are suitable for mice but could be different in humans. Usually, mice receive much higher doses for the same condition than would humans, as direct extrapolations of doses of drugs from animals to humans on $\mathrm{mg} / \mathrm{kg}$ basis cannot be achieved. There are species-specific differences in their metabolism, excretion, absorption, biotransformation, and pharmacokinetics. ${ }^{52,53}$ Therefore, calculations of doses cannot be made by simple mathematical equations. Small laboratory animals have high rates of metabolism and therefore use a larger dose for the same effect as that used in larger animals. ${ }^{54}$ Also, in pregnancy the pharmacokinetic parameters of an AED are altered, thereby requiring larger doses to produce the desired antiepileptic effect. ${ }^{55}$ There is not much information on the changes to the pharmacokinetics of H3R antagonist 2-18 during pregnancy. We administered H3R antagonist 2-18 during organogenesis (GD 8) as susceptibility to congenital malformations is greatest during this period and during the fetal period (GD 13) where growth could be affected. Implantation of embryos was not affected and fetal losses were no different than in the saline-treated mice even in the higher dose of $60 \mathrm{mg} / \mathrm{kg}$ or in those given multiple doses of the drug. In comparison with other AEDs, the tested compound 2-18 does seem to have minimal teratological effects, but it should be tested over the whole course of pregnancy to ensure that no cumulative effects occur.

\section{Conclusion}

The results observed for H3R antagonist 2-18 in the current studies show that it has the potential of being a very effective
AED and could also be used in pregnancy; however, more studies, in which H3R antagonist 2-18 is given over the entire course of gestation, are needed to assess whether these results could be replicated before this drug is approved.

\section{Acknowledgments}

Salim M Bastaki and Bassem Sadek were supported by intermural funds from College of Medicine and Health Sciences and the Office of Graduate Studies and Research, UAE University. The authors acknowledge the partial support of Polish Scientific Program K/ZDS/007121. Support was kindly provided by the EU COST Action CA151315 (KKK; MW). The authors thank Dr Abderrahim Oulhaj, Institute of Public Health, College of Medicine and Health Sciences, UAE, for his support and efforts in regard to revising statistical analyses.

\section{Disclosure}

The authors report no conflicts of interest in this work.

\section{References}

1. Fisher RS. Commentary: consciousness of epilepsy. Epilepsia. 2014; 55(8): 1153 .

2. Fisher RS, van Emde Boas W, Blume W, et al. Epileptic seizures and epilepsy: definitions proposed by the International League Against Epilepsy (ILAE) and the International Bureau for Epilepsy (IBE). Epilepsia. 2005;46(4):470-472.

3. Ngugi AK, Kariuki SM, Bottomley C, Kleinschmidt I, Sander JW, Newton CR. Incidence of epilepsy: a systematic review and metaanalysis. Neurology. 2011;77(10):1005-1012.

4. Kamei C, Ishizawa K, Kakinoki H, Fukunaga M. Histaminergic mechanisms in amygdaloid-kindled seizures in rats. Epilepsy Res. 1998; 30(3):187-194.

5. Kamei C, Ohuchi M, Sugimoto Y, Okuma C. Mechanism responsible for epileptogenic activity by first-generation H1-antagonists in rats. Brain Res. 2000;887(1):183-186.

6. Kamei C. Involvement of central histamine in amygdaloid kindled seizures in rats. Behav Brain Res. 2001;124(2):243-250.

7. Kamei C, Okumura Y, Tasaka K. Influence of histamine depletion on learning and memory recollection in rats. Psychopharmacology (Berl). 1993;111(3):376-382.

8. Kamei C, Okumura Y, Tsujimoto S, Tasaka K. Role of hypothalamic histamine in stimulating the corticosterone release in rats. Arch Int Pharmacodyn Ther. 1993;325:35-50.

9. Zhang LS, Chen Z, Huang YW, Hu WW, Wei EQ, Yanai K. Effects of endogenous histamine on seizure development of pentylenetetrazoleinduced kindling in rats. Pharmacology. 2003;69(1):27-32.

10. Sadek B, Kuder K, Subramanian D, et al. Anticonvulsive effect of nonimidazole histamine H3 receptor antagonists. Behav Pharmacol. 2014; 25(3):245-252.

11. Sadek B, Saad A, Latacz G, et al. Non-imidazole-based histamine $\mathrm{H} 3$ receptor antagonists with anticonvulsant activity in different seizure models in male adult rats. Drug Des Devel Ther. 2016;10: 3879-3898.

12. Sadek B, Saad A, Sadeq A, Jalal F, Stark H. Histamine H3 receptor as a potential target for cognitive symptoms in neuropsychiatric diseases. Behav Brain Res. 2016;312:415-430.

13. Sadek B, Saad A, Schwed JS, Weizel L, Walter M, Stark H. Anticonvulsant effects of isomeric nonimidazole histamine $\mathrm{H} 3$ receptor antagonists. Drug Des Devel Ther. 2016;10:3633-3651. eCollection 2016. 
14. Sadek B, Saad A, Subramanian D, Shafiullah M, Łażewska D, KiećKononowiczc K. Anticonvulsant and procognitive properties of the non-imidazole histamine $\mathrm{H} 3$ receptor antagonist DL77 in male adult rats. Neuropharmacology. 2016;106:46-55.

15. Sadek B, Schwed JS, Subramanian D, et al. Non-imidazole histamine $\mathrm{H} 3$ receptor ligands incorporating antiepileptic moieties. Eur J Med Chem. 2014;77:269-279.

16. Sadek B, Shehab S, Więcek M, et al. Anticonvulsant properties of histamine $\mathrm{H} 3$ receptor ligands belonging to N-substituted carbamates of imidazopropanol. Bioorg Med Chem Lett. 2013;23(17): 4886-4891.

17. Sadek B, Stark H. Cherry-picked ligands at histamine receptor subtypes. Neuropharmacology. 2016;106:56-73.

18. Chen Z, Li WD, Zhu LJ, Shen YJ, Wei EQ. Effects of histidine, a precursor of histamine, on pentylenetetrazole-induced seizures in rats. Acta Pharmacol Sin. 2002;23(4):361-366.

19. Miyata I, Saegusa H, Sakurai M. Seizure-modifying potential of histamine H1 antagonists: a clinical observation. Pediatr Int. 2011;53(5) 706-708.

20. Jang DH, Manini AF, Trueger NS, et al. Status epilepticus and widecomplex tachycardia secondary to diphenhydramine overdose. Clin Toxicol (Phila). 2010;48(9):945-948.

21. Arrang JM, Garbarg M, Schwartz JC. Auto-inhibition of brain histamine release mediated by a novel class (H3) of histamine receptor. Nature. 1983;302(5911):832-837.

22. Lovenberg TW, Roland BL, Wilson SJ, et al. Cloning and functional expression of the human histamine H3 receptor. Mol Pharmacol. 1999;55(6):1101-1107.

23. Vohora D, Saraogi P, Yazdani MA, Bhowmik M, Khanam R, Pillai KK. Recent advances in adjunctive therapy for epilepsy: focus on sodium channel blockers as third-generation antiepileptic drugs. Drugs Today (Barc). 2010;46(4):265-277.

24. Witkin JM, Nelson DL. Selective histamine H3 receptor antagonists for treatment of cognitive deficiencies and other disorders of the central nervous system. Pharmacol Ther. 2004;103(1):1-20.

25. Fisher RS, Acevedo C, Arzimanoglou A, et al. ILAE official report: a practical clinical definition of epilepsy. Epilepsia. 2014;55(4): 475-482.

26. Schwartz JC. The histamine $\mathrm{H} 3$ receptor: from discovery to clinical trials with pitolisant. Br J Pharmacol. 2011;163(4):713-721.

27. Kuhne S, Wijtmans M, Lim HD, Leurs R, de Esch IJ. Several down, a few to go: histamine $\mathrm{H} 3$ receptor ligands making the final push towards the market? Expert Opin Investig Drugs. 2011;20(12): 1629-1648.

28. Kasteleijn-Nolst Trenité D, Parain D, Genton P, Masnou P, Schwartz JC, Hirsch E. Efficacy of the histamine 3 receptor (H3R) antagonist pitolisant (formerly known as tiprolisant; BF2.649) in epilepsy: dosedependent effects in the human photosensitivity model. Epilepsy Behav. 2013;28(1):66-70.

29. Kieć-Kononowicz K, Wiecek M, Sasse A, et al. Importance of the lipophilic group in carbamates having histamine H3-receptor antagonist activity. Pharmazie. 2000;55(5):349-355.

30. Sander K, Kottke T, Weizel L, Stark H. Kojic acid derivatives as histamine H(3) receptor ligands. Chem Pharm Bull (Tokyo). 2010;58(10): 1353-1361.

31. Sadek B, Schreeb A, Schwed JS, Weizel L, Stark H. Drug-likeness approach of 2-aminopyrimidines as histamine $\mathrm{H} 3$ receptor ligands. Drug Des Devel Ther. 2014;8:1499-1513.

32. Sadek B, Khanian SS, Ashoor A, et al. Effects of antihistamines on the function of human $\alpha 7$-nicotinic acetylcholine receptors. Eur $J$ Pharmacol. 2015;746:308-316.

33. Alachkar A, Lazewska D, Kiec-Kononowicz K, Sadek B. The histamine H3 receptor antagonist E159 reverses memory deficits induced by dizocilpine in passive avoidance and novel object recognition paradigm in rats. Front Pharmacol. 2017;8:709.

34. Kamińska K, Ziemba J, Ner J, et al. (2-Arylethenyl)-1,3,5-triazin-2amines as a novel histamine $\mathrm{H} 4$ receptor ligands. Eur J Med Chem. 2015;103:238-251.
35. Kamiński K, Rapacz A, Łuszczki JJ, et al. Design, synthesis and biological evaluation of new hybrid anticonvulsants derived from N-benzyl-2-(2,5-dioxopyrrolidin-1-yl)propanamide and 2-(2,5dioxopyrrolidin-1-yl)butanamide derivatives. Bioorg Med Chem. 2015;23(10):2548-2561.

36. Obniska J, Rapacz A, Rybka S, et al. Synthesis, and anticonvulsant activity of new amides derived from 3-methyl- or 3-ethyl-3-methyl2,5-dioxo-pyrrolidin-1-yl-acetic acids. Bioorg Med Chem. 2016;24(8): 1598-1607.

37. Obniska J, Rapacz A, Rybka S, et al. Design, synthesis and biological activity of new amides derived from 3-methyl-3-phenyl-2,5-dioxopyrrolidin-1-yl-acetic acid. Eur J Med Chem. 2015;102:14-25.

38. Siddiqui N, Ahsan W. Triazole incorporated thiazoles as a new class of anticonvulsants: design, synthesis and in vivo screening. Eur J Med Chem. 2010;45(4):1536-1543.

39. Sterz H, Lehmann H. A critical comparison of the freehand razor-blade dissection method according to Wilson with an in situ sectioning method for rat fetuses. Teratog Carcinog Mutagen. 1985;5(5):347-354.

40. Kakinoki H, Ishizawa K, Fukunaga M, Fujii Y, Kamei C. The effects of histamine H3-receptor antagonists on amygdaloid kindled seizures in rats. Brain Res Bull. 1998;46(5):461-465.

41. Bhowmik M, Khanam R, Vohora D. Histamine H3 receptor antagonists in relation to epilepsy and neurodegeneration: a systemic consideration of recent progress and perspectives. Br J Pharmacol. 2012;167(7): 1398-1414.

42. Belelli D, Lan NC, Gee KW. Anticonvulsant steroids and the GABA/ benzodiazepine receptor-chloride ionophore complex. Neurosci Biobehav Rev. 1990;14(3):315-322.

43. Belelli D, McCauley L, Gee KW. Heterotropic cooperativity between putative recognition sites for progesterone metabolites and the atypical benzodiazepine Ro 5-4864. J Neurochem. 1990;55(1):83-87.

44. Lan NC, Chen JS, Belelli D, Pritchett DB, Seeburg PH, Gee KW. A steroid recognition site is functionally coupled to an expressed GABA(A)benzodiazepine receptor. Eur J Pharmacol. 1990;188(6):403-406.

45. Maguire JL, Stell BM, Rafizadeh M, Mody I. Ovarian cycle-linked changes in $\mathrm{GABA}(\mathrm{A})$ receptors mediating tonic inhibition alter seizure susceptibility and anxiety. Nat Neurosci. 2005;8(6):797-804.

46. Holmes LB, Harvey EA, Coull BA, et al. The teratogenicity of anticonvulsant drugs. N Engl J Med. 2001;344(15):1132-1138.

47. Kaplan PW. Reproductive health effects and teratogenicity of antiepileptic drugs. Neurology. 2004;63(10 Supp1 4):S13-S23.

48. Padmanabhan R, Shafiullah M, Benedict S, Nagelkerke N. Effect of maternal exposure to homocystine on sodium valproate-induced neural tube defects in the mouse embryos. Eur J Nutr. 2006;45(6): 311-319.

49. Abdulrazzaq YM, Bastaki SM, Padmanabhan R. Teratogenic effects of vigabatrin in TO mouse fetuses. Teratology. 1997;55(3):165-176.

50. Abdulrazzaq YM, Padmanabhan R, Bastaki SM, Ibrahim A, Nurulain M, Shafiullah M. Effect of maternal administration of vigabatrin during late gestation on fetoplacental amino acid profile in the mouse. Reprod Toxicol. 2005;20(4):549-560.

51. Padmanabhan R, Abdulrazzaq YM, Bastaki SM, Shafiullah M, Chandranath SI. Experimental studies on reproductive toxicologic effects of lamotrigine in mice. Birth Defects Res B Dev Reprod Toxicol. 2003;68(5):428-438.

52. Lin JH, Lu AY. Role of pharmacokinetics and metabolism in drug discovery and development. Pharmacol Rev. 1997;49(4):403-449.

53. Adelman R, Saul RL, Ames BN. Oxidative damage to DNA: relation to species metabolic rate and life span. Proc Natl Acad Sci U S A. 1988;85(8):2706-2708.

54. Kirkwood JK. Influence of body size in animals on health and disease. Vet Rec. 1983;113(13):287-290.

55. Tomson T, Battino D. Pharmacokinetics and therapeutic drug monitoring of newer antiepileptic drugs during pregnancy and the puerperium Clin Pharmacokinet. 2007;46(3):209-219.

56. Więcek M, Kottke T, Ligneau X, et al. N-Alkenyl and cycloalkyl carbamates as dual acting histamine $\mathrm{H} 3$ and $\mathrm{H} 4$ receptor ligands. Bioorg Med Chem. 2011;19(9):2850-2858. 
57. Fahim MA, Nemmar A, Singh S, Hassan MY. Antioxidants alleviate nicotine-induced platelet aggregation in cerebral arterioles of mice in vivo. Physiol Res. 2011;60(4):695-700.
58. Nemmar A, Al-Salam S, Zia S, et al. Contrasting actions of diesel exhaust particles on the pulmonary and cardiovascular systems and the effects of thymoquinone. Br J Pharmacol. 2011;164(7):1871-1882.

\section{Publish your work in this journal}

Drug Design, Development and Therapy is an international, peerreviewed open-access journal that spans the spectrum of drug design and development through to clinical applications. Clinical outcomes, patient safety, and programs for the development and effective, safe, and sustained use of medicines are the features of the journal, which has also been accepted for indexing on PubMed Central. The manuscript management system is completely online and includes a very quick and fair peer-review system, which is all easy to use. Visit http://www.dovepress.com/testimonials.php to read real quotes from published authors.

Submit your manuscript here: http://www.dovepress.com/drug-design-development-and-therapy-journal 